\title{
KEMAMPUAN TOLERANSI EMPAT GENUS TANAMAN HIAS TERHADAP CEKAMAN LOGAM TIMBAL (Pb)
}

\author{
Nurul Muddarisna ${ }^{1)}$, Yekti Sri Rahayu ${ }^{2)}$ \\ ${ }^{1}$ Fak.Pertanian,Univ. Wisnuwardhana Malang \\ email: Nurulmudarisna@yahoo.co..id \\ ${ }^{2}$ Fak.Pertanian, Univ. Wisnuwardhana Malang \\ email: yektisr@ymail.com
}

\begin{abstract}
ABSTRAK
Logam berat timbal $(\mathrm{Pb})$ yang dihasilkan dari sisa hasil pembakaran tidak sempurna dapat menimbulkan racun yang dapat mencemari tanah sehingga dapat berpengaruh terhadap tanaman yang tumbuh di atasnya. Secara umum tanaman peka terhadap lingkungan tumbuh yang tercemar unsur logam berat dikarenakan unsur tersebut tidak dibutuhkan tanaman dan bersifat toksik. Pengaruh meracun logam berat terhadap tanaman dapat bersifat kronis dan akut ditentukan oleh lama kontak, konsentrasi dan daya tahan tanaman. Tujuan penelitian ini adalah untuk mendapatkan genus tanaman hias yang mempunyai kemampuan toleransi paling tinggi terhadap cekaman logam berat timbal $(\mathrm{Pb})$. Penelitian ini menggunakan metode Rancangan Acak kelompok (RAK) dengan faktor pertama: macam genus tanaman hias dan faktor kedua: konsentrasi logam berat timbal $(\mathrm{Pb})$. Hasil penelitian menunjukkan kemampuan toleransi dan adaptasi tanaman genus Codiaeum terhadap paparan berbagai taraf konsentrasi logam timbal $(\mathrm{Pb})$ cenderung lebih tinggi dibanding genus Heliconia, Eichornia dan Marantha. Rata-rata tinggi tanaman dan jumlah daun per tanaman dari empat genus tanaman hias (Codiaeum, Heliconia, Marantha dan Eichornia) menurun secara nyata pada taraf konsentrasi $1200 \mathrm{mg} \mathrm{Pb} \cdot \mathrm{kg}^{-1} \mathrm{~Pb}$ sementara rata-rata luas daun per tanaman menurun secara nyata pada taraf konsentrasi $400 \mathrm{mg} \mathrm{Pb} \cdot \mathrm{kg}^{-1}$ dibanding kontrol selama umur 5 minggu setelah tanam.
\end{abstract}

\begin{abstract}
Lead $(\mathrm{Pb})$ heavy metals produced from the waste of incomplete combustion cause toxins that contaminate the soil so that affecting the plants growth. Generally, plants are susceptive on heavy metal contaminated environment because these elements are unessential and toxic. Toxicity of heavy metal are chronic and acute, it can be determined by the duration of contact, concentration and tolerance of plant. This study aims to obtain ornamental plants that have the highest tolerance capability against lead $(\mathrm{Pb})$ heavy metal stressing. This study uses randomized block design (RBD) with the first factor is a kind of ornamental plants and the second factor is the concentration of lead $(\mathrm{Pb})$ heavy metal. The results show that the ability of tolerance and adaptability of genus Codiaeum against exposure variety of lead $(\mathrm{Pb})$ concentration level tend to be higher than genus Heliconia, Eichornia and Marantha. The average of plant height and number of leaves per plant of four ornamental plants genus decreased significantly on $1200 \mathrm{mg} \mathrm{Pb} \cdot \mathrm{kg}^{-1}$, while the average of leaf area per plant decreased significantly on $400 \mathrm{mg} \mathrm{Pb} . \mathrm{kg}^{-1}$ compared to the control over 5 weeks after planting.
\end{abstract}

Keywords: tolerance, ornamental plant, stress,lead. 
PENDAHULUAN

Gas-gas buangan yang berasal dari kendaraan bermotor mengakibatkan pencemaran dan menurunkan kualitas lingkungan, karena menghasilkan polutan yang tinggi setiap tahunnya. Salah satu jenis bahan bakar yang banyak digunakan masyarakat Indonesia adalah jenis premium yang mempunyai nilai oktan 88 dengan kandungan timbal (tetraethyl lead) 3 g.. $\mathrm{L}^{-1}$. Menurut Environment Protection Agency (EPA), batas maksimum timbal dalam 1 liter bensin adalah 0,05 gram. Kandungan timbal diperkirakan $90 \%$ keluar bersama gas buangan knalpot dan dapat terhirup maupun terserap oleh tubuh makhluk hidup ( Wagiu dan Wulur, 2006). Gusnita (2012) dalam artikelnya memaparkan bahwa logam $\mathrm{Pb}$ yang terkandung dalam bensin sangatlah berbahaya, sebab pembakaran bensin akan mengemisikan 0,09 gram timbal tiap $1 \mathrm{~km}$. Limbah dari pencemaran udara dapat menyebabkan penurunan kualitas lingkungan, karena dapat merusak sumberdaya alam yang ada.

Logam berat timbal $(\mathrm{Pb})$ yang dihasilkan dari sisa hasil pembakaran tidak sempurna dapat menimbulkan racun yang dapat mencemari tanah sehingga dapat berpengaruh terhadap tanaman yang tumbuh di atasnya. Secara umum tanaman peka terhadap lingkungan tumbuh yang tercemar unsur logam berat dikarenakan unsur tersebut tidak dibutuhkan tanaman dan bersifat toksik. Pengaruh meracun logam berat terhadap tanaman dapat bersifat kronis dan akut ditentukan oleh lama kontak, konsentrasi dan daya tahan tanaman.

Ada tumbuhan yang memiliki sifat toleran dan hiperakumulator terhadap logam berat, dan merombak polutan, adapula tumbuhan yang telah dimodifikasi secara genetic untuk mengontrol mikroba, sekaligus tanaman tersebut memiliki nilai estetika (Feller, 2000). Menurut Hidayati (2005) karakteristik tumbuhan hiperakumulator yaitu tahan terhadap unsure logam dalam konsentrasi tinggi pada jaringan akar dan tajuk, tingkat laju penyerapan unsure dari tanah yang tinggi dibanding tanaman yang lain, dan memiliki kemampuan translokasi dan mengakumulasi unsure logam dari akar ke tajuk dengan laju yang tinggi. Beberapa penelitian tentang potensi tanaman hutan kota maupun tanaman taman kota telah banyak dilakukan terutama pada kemampuan sejenis tanaman pohon dalam menyerap gas-gas sumber polutan di udara. Sementara itu kajian tentang nilai ekologis tanaman hias pengisi taman kota dalam menyerap polutan di udara masih banyak yang menarik untuk diteliti. Hal ini menarik untuk dikaji mengingat tanaman-tanaman hias pengisi taman kota, selain memiliki nilai estetika juga memiliki potensi nilai ekologis dalam menjaga kualitas lingkungan. Informasi teknis dari Dirjen Hortikultura (2012) disebutkan bahwa diantara beberapa tanaman hias pot maupun lansekap yang memiliki potensi sebagai penyerap polutan diantaranya adalah dari Genus Bougenvillea, Polyscias, Hibiscus, Jacobinia, dalam menyerap gas-gas $\mathrm{NO}_{2}$, 
kemudian ada pula tanaman hias yang memiliki kemampuan mendekomposisi polutan formaldehida dan polutan gas organic lainnya seperti dari Genus Sanseivera, Philodendron, Scindapsus, Aglaonema, Adiantum, Syngonium, Dracaena, dan lainlain. Sementara itu ada pula tanaman hias yang berpotensi dalam menyerap polutan gasgas lainnya termasuk logam berat, seperti dari genus Eichornia, Marantha, Heliconia, Chamaedorea, Codiaeum, Bromelia, dan lainlain. Tujuan penelitian ini adalah untuk mendapatkan genus tanaman hias yang selain memiliki nilai estetika juga mempunyai kemampuan toleransi paling tinggi terhadap cekaman logam berat timbal $(\mathrm{Pb})$.

\section{METODE PENELITIAN}

Penelitian dilaksanakan di rumah kaca, kebun percobaan Fakultas Pertanian Universitas Wisnuwardhana Kota Malang dengan ketinggian tempat sekitar $550 \mathrm{~m} \mathrm{dpl}$. Waktu pelaksanaan penelitian pada bulan Maret - Juni 2015.

Penelitian merupakan percobaan faktorial dengan menggunakan Rancangan Acak Kelompok (RAK). Faktor pertama adalah macam genus tanaman hias $(\mathrm{G})$ terdiri atas: Codieaum (G1), Heliconia (G2), Marantha (G3) dan Eichornia (G4). Faktor kedua adalah konsentrasi logam timbal $(\mathrm{P})$, terdiri atas: tanpa logam timbal (P0), $400 \mathrm{mg} \mathrm{Pb} \cdot \mathrm{kg}^{-1}$ (P1), $800 \mathrm{mg} \mathrm{Pb.kg}{ }^{-1}$ (P2) dan $1200 \mathrm{mg}$ Pb.kg ${ }^{-1} \quad$ (P3). Perlakuan merupakan kombinasi kedua faktor yang diulang sebanyak tiga kali sehingga terdapat 48 unit percobaan.

Percobaan menggunakan polibag ukuran $40 \mathrm{~cm} \times 40 \mathrm{~cm}$ dengan media tanam berupa tanah dari jenis Inceptisol yang tidak mengandung cemaran logam timbal. Tanah yang digunakan sebagai media tanam adalah tanah dalam kondisi kering udara dengan ukuran lolos ayakan $2 \mathrm{~mm}$ seberat $10 \mathrm{~kg}$. Bahan tanam menggunakan bibit tanaman hias berumur kurang lebih 2 bulan yang berupa stek batang untuk genus Codiaeum, rhizome untuk genus Heliconia, anakan untuk genus Marantha dan Eichornia. Parameter pengamatan meliputi: tinggi tanaman, jumlah daun dan luas daun per tanaman.

Data yang diperoleh dari hasil pengamatan pertumbuhan vegetatif sebagai respon tingkat kemampuan toleransi tanaman hias dianalisis dengan Analisis Varian (ANOVA). Jika terdapat pengaruh nyata dari faktor yang diberikan dilanjutkan pengujian dengan Uji Beda Nyata Terkecil (BNT) taraf $5 \%$.

\section{HASIL DAN PEMBAHASAN}

Secara umum tanaman peka terhadap cekaman logam berat yang terdapat dilingkungan tumbuhnya. Perbedaan toleransi tanaman terhadap logam berat sangat bervariasi antar tanaman. Sensitifitas dan toleransi tanaman terhadap logam berat dipengaruhi oleh spesies dan genotyp tanaman (Tlustos et al., 2006). Pengaruh toksik logam berat terhadap tanaman dapat dilihat baik dari gejala struktural maupun 
gangguan fisiologis. Pengaruh meracun logam berat terhadap tanaman dapat bersifat kronis dan akut ditentukan oleh lama kontak, konsentrasi dan daya tahan tanaman. Tanaman dapat mengembangkan beberapa mekanisme efektif untuk toleran terhadap kadar logam yang tinggi dalam tanah. Percobaan menggunakan parameter laju pertumbuhan tanaman merupakan pengujian secara kuantitatif tingkat toksisitas unsur logam dan daya toleransi tanaman terhadap suatu cekaman logam.

\section{Tinggi Tanaman}

Hasil pengujian kemampuan toleransi empat genus tanaman hias terhadap cekaman logam berat sampai umur 5 minggu setelah tanam menunjukkan bahwa semua tanaman cukup toleran terhadap tanah yang terkontaminasi timbal $(\mathrm{Pb})$ karena tidak diketemukan adanya gejala keracunan atau kerusakan fisik pada tanaman walaupun terjadi hambatan pertumbuhan tanaman.

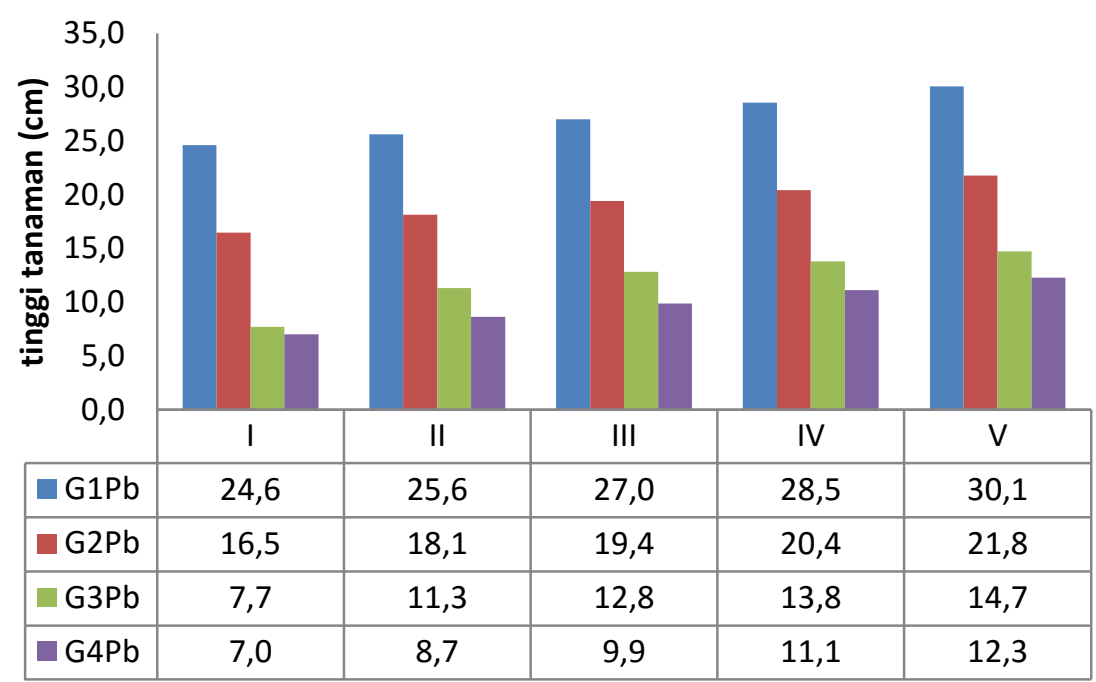

Gambar 1. Pertumbuhan tinggi tanaman $(\mathrm{cm}) 4$ genus tanaman hias sebagai pengaruh perlakuan konsentrasi logam timbal $(\mathrm{Pb})$ selama 5 minggu setelah tanam

Keterangan: G1=Codiaeum; G2= Heliconia; G3= Marantha; G4= Eichornia

Timbal $(\mathrm{Pb})$ adalah logam berat yang tidak dibutuhkan tanaman dan bersifat toksik yang dapat diakumulasi didalam organ tanaman (Mahmoud and El-Beltagy, 1998). Berdasarkan atas sifat toksisitasnya, unsur timbal $(\mathrm{Pb})$ termasuk dalam kategori logam berat yang bersifat toksik tinggi. Hasil pengujian kemampuan toleransi empat genus tanaman hias terhadap paparan berbagai konsentrasi logam timbal sebagaimana terlihat pada Gambar 1 menunjukkan bahwa tanaman genus Marantha (G3) memiliki ratarata laju pertumbuhan tinggi tanaman paling besar, pada perlakuan berbagai konsentrasi logam timbal $(\mathrm{Pb})$, diikuti oleh genus Codiaeum(G1), Heliconia (G2), dan Eichornia (G4). Hal ini menunjukkan kemampuan toleransi tanaman genus maranta 
(G3) terhadap pencemar timbal cenderung lebih besar dibanding ketiga genus lainnya dimana adanya pencemar timbal dalam media tanamnya masih dapat ditoleransi sehingga walau terjadi penghambatan pertumbuhan, tetapi penurunan pertumbuhannya relative lebih kecil sehingga masih mampu menghasilkan laju pertumbuhan tinggi tanaman yang lebih besar dibanding ketiga genus lainnya.

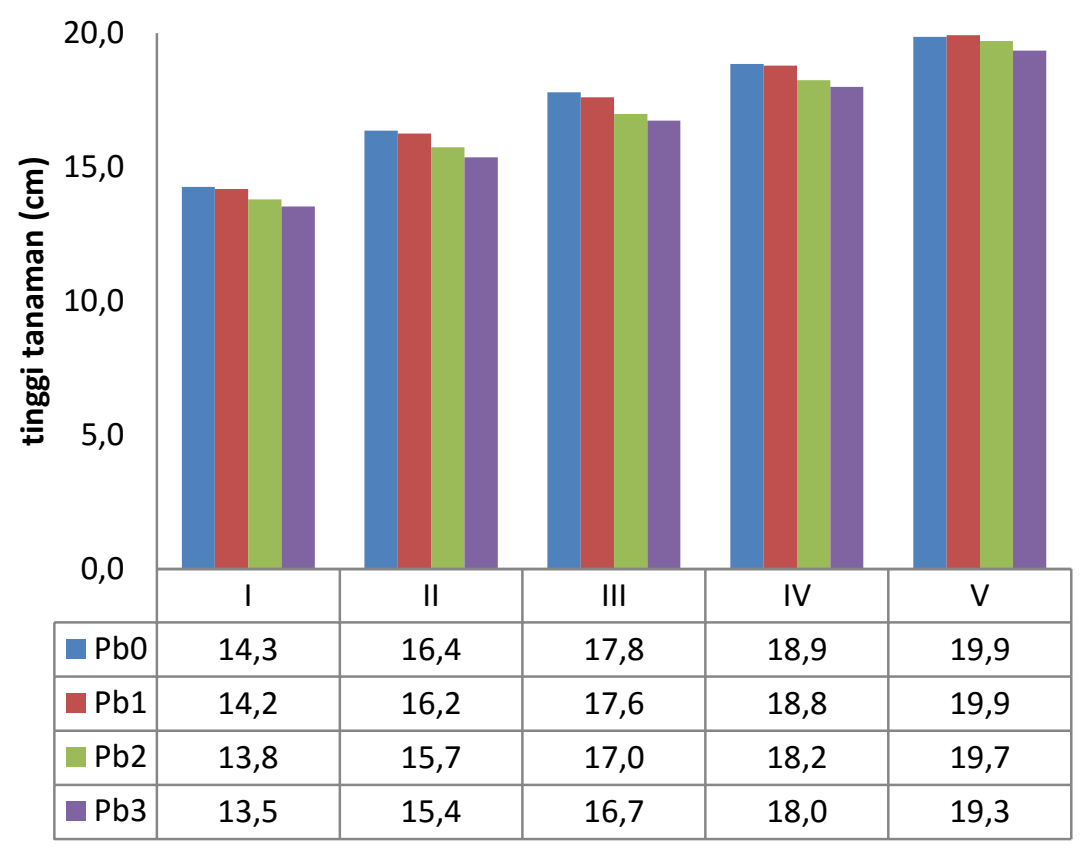

Gambar 2. Rata-rata tinggi tanaman $(\mathrm{cm})$ empat genus tanaman hias pada berbagai konsentrasi logam timbal $(\mathrm{Pb})$ selama 5 minggu setelah tanam

Keterangan: $\mathrm{Pb} 0=0 \mathrm{mg} \mathrm{Pb} \cdot \mathrm{kg}^{-1} ; \mathrm{Pb} 1=400 \mathrm{mg} \mathrm{Pb} \cdot \mathrm{kg}^{-1} ; \mathrm{Pb} 2=800 \mathrm{mg} \mathrm{Pb} \cdot \mathrm{kg}^{-1} ; \mathrm{Pb} 3=$ $1200 \mathrm{mg} \mathrm{Pb} \cdot \mathrm{kg}^{-1}$

Suatu tanaman walaupun memiliki kemampuan beradaptasi untuk bertahan hidup dalam lingkungan yang tercekam logam berat namun semakin meningkat tingkat cekaman seiring dengan meningkatnya kadar logam berat dalam media tanam dapat mengakibatkan terjadinya perubahan fisiologi yang diekspresikan dalam gangguan pertumbuhan, apabila senyawa logam berat terlarut terambil oleh tanaman.

Hasil pengamatan terhadap tinggi tanaman selama umur 5 minggu setelah tanam sebagai pengaruh perlakuan berbagai taraf konsentrasi logam timbal $(\mathrm{Pb})$ terhadap laju pertumbuhan tinggi tanaman empat genus tanaman hias: Codieaum (G1), Heliconia (G2), Marantha (G3) dan Eichornia (G4), sebagaimana tersaji pada Gambar 2 menunjukkan bahwa pertumbuhan tinggi tanaman empat genus tanaman hias tersebut terpengaruh pada semua taraf konsentrasi logam timbal. Pada umur 5 minggu setelah tanam rata-rata tinggi tanaman keempat genus tanaman hias terjadi penurunan secara nyata $(\mathrm{P}=<0.05)$ pada taraf konsentrasi logam timbal $(\mathrm{Pb})$ sebesar $1200 \quad \mathrm{mg} \quad \mathrm{Pb}^{\mathrm{kg}}{ }^{-1}$ 
dibanding yang tidak dilakukan penambahan pencemar timbal.

Semakin meningkat konsentrasi logam berat dalam media tanam umumnya akan diikuti dengan peningkatan serapan oleh tanaman. Hal ini disebabkan adanya perbedaan konsentrasi logam berat antara dua jenis media yaitu media dalam jaringan tanaman dan media tanam. Perbedaan konsentrasi ini akan menyebabkan terjadinya perpindahan atau tranfer massa (logam berat) secara difusi dan osmosis dimana massa zat dengan konsentrasi yang tinggi akan berpindah ke media dengan konsentrasi yang rendah. Keberadaan logam berat dalam media tanam pada konsentrasi yang tinggi dapat mengakibatkan sulitnya tanaman memperoleh unsur hara karena adanya kompetisi antara ion-ion, dimana akar-akar tanaman mengabsorbsi ion dari media kompleks yang mengandung tidak hanya satu atau lebih ion hara yang esensial tetapi juga ion non esensial (termasuk logam berat) dan senyawa organik. Logan $\mathrm{Pb}$ yang diakumulasi dalam tanaman akan menurunkan laju pertumbuhan dan menurunkan serapan mineral esensial dari dalam tanah (Lamhamdi et al., 2013). Apabila terjadi ketidakseimbangan yang berat dalam suplai ini, tanaman mungkin tidak mampu mengambil hara secara efisien baik karena pengaruh langsung dari ion-ion toksik pada metabolisme atau fungsi akar atau karena adanya kompetisi atau interaksi dengan ionion hara.

\section{Jumlah Daun}

Spesies tumbuhan secara genetis sangat beragam dalam kemampuannya untuk toleran atau tidak toleran terhadap unsur non esensial dalam jumlah yang meracuni. Tumbuhan mengembangkan sistem metabolik yang dapat berfungsi pada konsentrasi toksik. Hasil pengamatan terhadap jumlah daun per tanaman pada perlakuan berbagai konsentrasi logam timbal $(\mathrm{Pb})$ selama 5 minggu setelah tanam sebagaimana tersaji dalam Gambar 3 menunjukkan bahwa tanaman genus Eichornia (G4) memiliki rata-rata pertumbuhan jumlah daun pertanaman paling besar, diikuti oleh genus Codiaeum (G1), Marantha (G3) dan Heliconia (G2). Hal tersebut menunjukkan tanaman genus Eichornia (G4) memiliki kemampuan beradaptasi dan lebih toleran terhadap media tanam yang mengandung berbagai taraf konsentrasi logam timbal dibanding ketiga genus lainnya walau terjadi penghambatan pertumbuhannya tetapi masih mampu menghasilkan jumlah daun yang lebih banyak dibanding ketiga genus lainnya. 


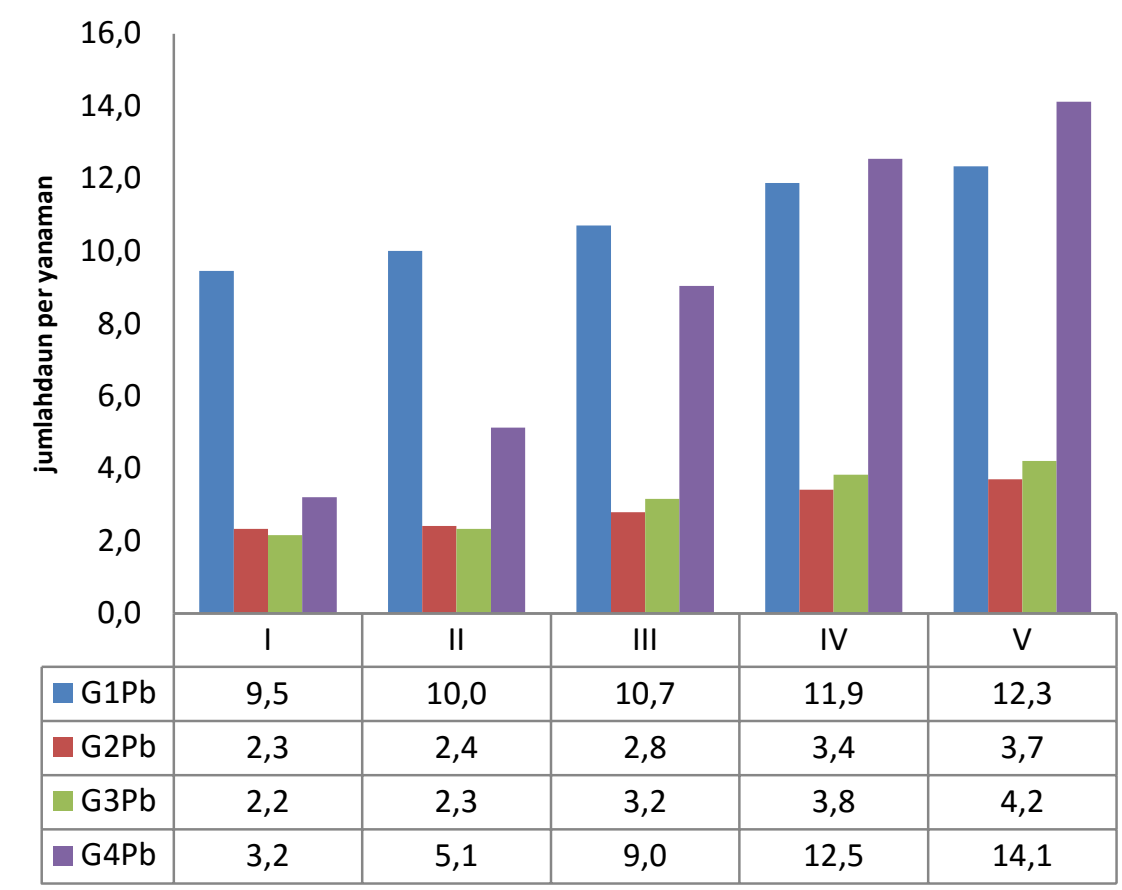

Gambar 3. Pertumbuhan jumlah daun pertanaman 4 genus tanaman hias sebagai pengaruh perlakuan konsentrasi logam timbal $(\mathrm{Pb})$ selama 5 minggu setelah tanam

Keterangan: G1=Codiaeum; G2= Heliconia; G3= Marantha; G4= Eichornia

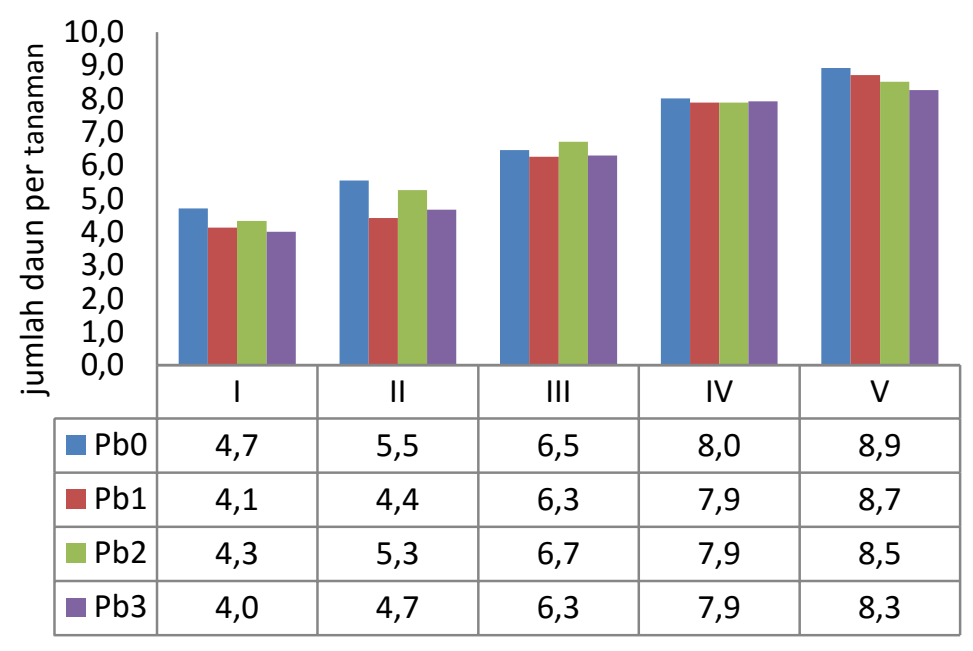

Gambar 4 Rata-rata jumlah daun pertanaman empat genus tanaman hias pada berbagai konsentrasi logam timbal $(\mathrm{Pb})$ selama umur 5 minggu setelah tanam

Keterangan: $\mathrm{Pb} 0=0 \mathrm{mg} \mathrm{Pb} \cdot \mathrm{kg}^{-1} ; \mathrm{Pb} 1=400 \mathrm{mg} \mathrm{Pb} \cdot \mathrm{kg}^{-1} ; \mathrm{Pb} 2=800 \mathrm{mg} \mathrm{Pb} \cdot \mathrm{kg}^{-1} ; \mathrm{Pb} 3=$ $1200 \mathrm{mg} \mathrm{Pb} \cdot \mathrm{kg}^{-1}$

Tanaman yang tergolong toleran logam (metallophytes) dapat mempertahankan penampilan atau pertumbuhannya yang baik karena dapat mengatasi kadar logam yang tinggi di dalam internal tubuhnya dikarenakan memiliki kemampuan beradaptasi (Ernst, 2006). Pada spesies tanaman yang toleran terhadap logam memiliki mekanisme 
pertahanan yang berkaitan dengan antioksidan sel dan enzim antioksidan yang melindungi beberapa aktivitas fisiologis vital untuk mengurangi kerusakan yang diakibatkan oleh bentuk-bentuk oksigen reaktif karena stress yang diakibatkan oleh adanya kandungan logam. Tingkat stres tanaman akan semakin meningkat seiring dengan peningkatan kadar logam berat di dalam lingkungan tumbuhnya. Peningkatakan kadar logam berat dalam media tanam dapat mengakibatkan terjadinya perubahan fisiologi yang diekspresikan dalam gangguan pertumbuhan, apabila senyawa logam berat terlarut terambil oleh tanaman.

Hasil pengamatan terhadap pertumbuhan jumlah daun pertanaman empat genus tanaman hias sampai umur 5 minggu setelah tanam sebagaimana tersaji pada Gambar 4 menunjukkan bahwa peningkatan konsentrasi timbal dalam media tanam cenderung diikuti dengan peningkatan penurunan pertumbuhan rata-rata jumlah daun per tanaman dari empat genus tanaman hias: Codiaeum (G1), Heliconia (G2), Marantha (G3) dan Eichornoa (G4) dibanding dengan kontrol (tanpa pencemar timbal). Sebagaimana pengaruhnya terhadap tinggi tanaman, pada umur 5 minggu setelah tanam, penurunan pertumbuhan ratarata jumlah daun empat genus tanaman hias tersebut secara nyata terjadi pada perlakuan pemberian pencemar logam timbal dengan taraf konsentrasi $1200 \mathrm{mg} \mathrm{Pb} \mathrm{Kg}^{-1}$ dibanding dengan yang tanpa dilakukan pemberian pencemar timbal atau kadmium (kontrol).

Hal ini selaras dengan hasil penelitian John et al. (2008) menunjukkan bahwa produksi biomasa Lemna polyrrhiza setelah umur 30 hari mengalami penurunan dibanding kontrol seiring dengan peningkatan konsentrasi logam timbal dalam media tanam dengan penurunan biomasa terjadi sangat nyata pada konsentrasi $40 \mathrm{mg} . \mathrm{L}^{-1}$ timbal $(\mathrm{Pb})$.

\section{Luas Daun}

Bahan pencemar dapat menyebabkan kerusakan fisiologis jauh di dalam tanaman sebelum terjadinya kerusakan fisik. Para ahli menyebutkannya sebagai kerusakan tersembunyi yang berupa kemampuan menyerap air dan pertumbuhan sel yang lambat atau pembukaan stomata yang tidak sempurna. Total luas daun (leaf area) tanaman yang terkena pencemaran akan mengalami penurunan karena terhambatnya laju pertumbuhan dan perluasan daun serta meningkatnya jumlah daun yang gugur, sehingga secara langsung atau tidak langsung akan menurunkan hasil fotosintensis. 


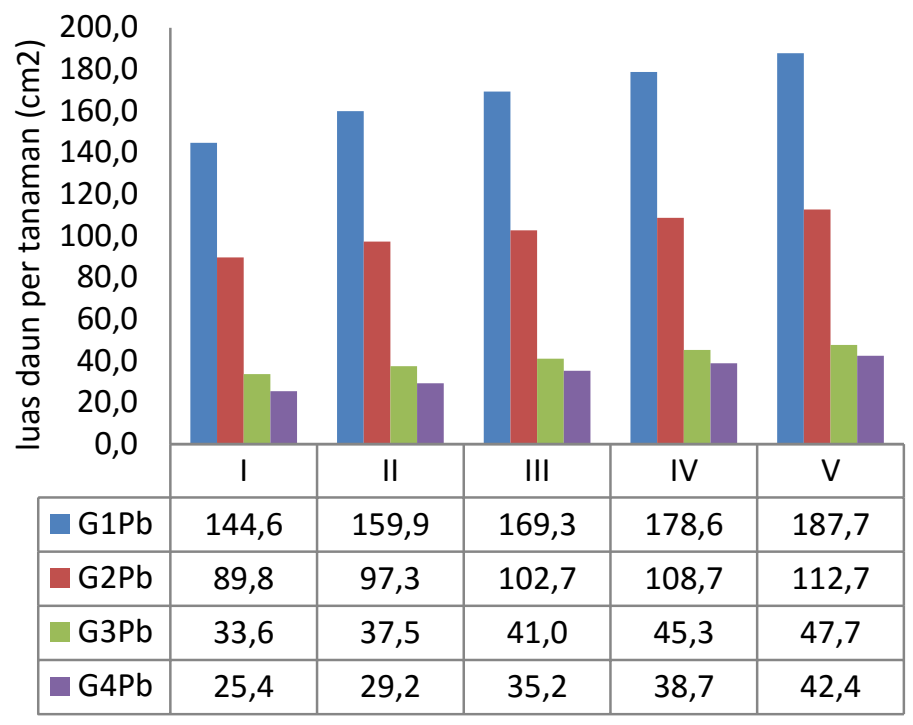

Gambar 5. Pertumbuhan luas daun per tanaman $\left(\mathrm{cm}^{2}\right)$ empat genus tanaman hias sebagai pengaruh perlakuan konsentrasi timbal $(\mathrm{Pb})$ selama 5 minggu setelah tanam.

Keterangan:G1=Codiaeum;G2= Heliconia; G3= Marantha; G4=Eichornia

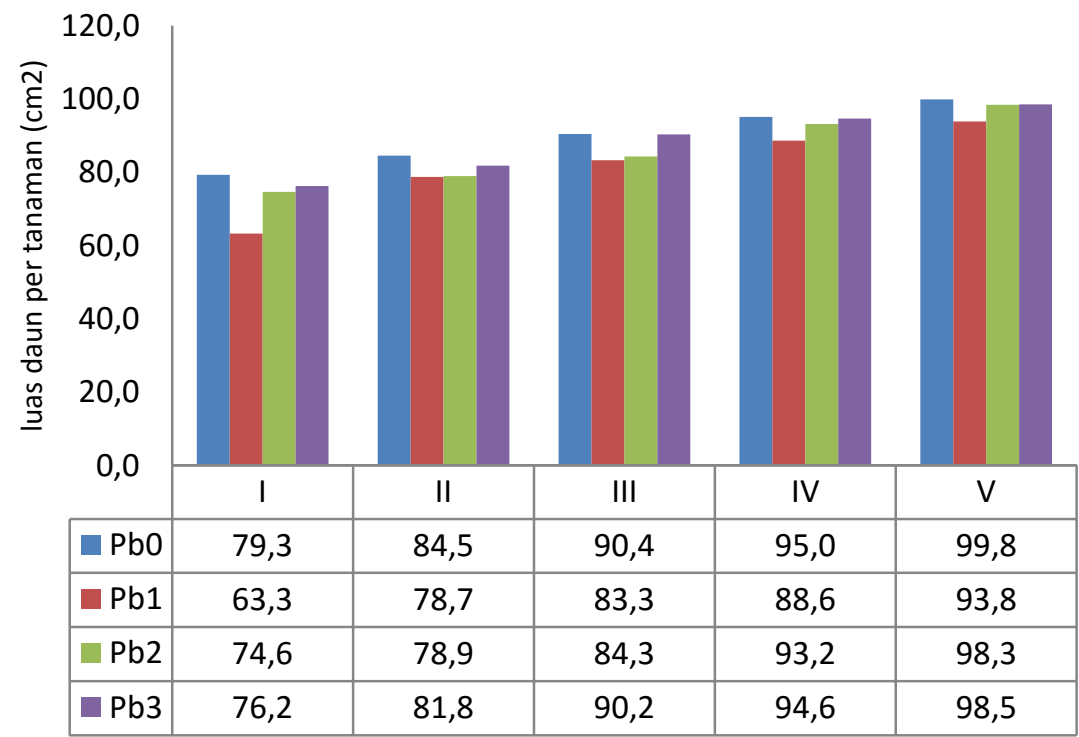

Gambar 6. Rata-rata luas daun per tanaman $\left(\mathrm{cm}^{2}\right)$ empat genus tanaman hias pada berbagai konsentrasi logam timbal $(\mathrm{Pb})$ selama 5 minggu setelah tanam

Keterangan: $\mathrm{Pb} 0=0 \mathrm{mg} \mathrm{Pb} . \mathrm{Kg}^{-1} ; \mathrm{Pb} 1=400 \mathrm{mg} \mathrm{Pb} . \mathrm{Kg}^{-1} ; \mathrm{Pb} 2=800 \mathrm{mg} \mathrm{Pb} . \mathrm{Kg}^{-1} ; \mathrm{Pb} 3=$ $1200 \mathrm{mg} \mathrm{Pb} . \mathrm{Kg}^{-1}$

Akumulasi $\mathrm{Pb}$ di dalam tanaman meningkat seiring dengan peningkatan level $\mathrm{Pb}$ di media. $\mathrm{Pb}$ dapat menyebabkan disfungsi fisiologi dan biokimia secara luas yang berpengaruh pada perkecambahan benih, pertumbuhan tanaman, status air dan asimilasi nitrat (Sharma dan Dubay, 2005). Konsentrasi timbal yang tinggi $\left(100-1000 \mathrm{mg} \mathrm{Pb} . \mathrm{Kg}^{-1}\right)$ akan mengakibatkan pengaruh toksik pada proses fotosintesis dan pertumbuhan. Timbal hanya mempengaruhi tanaman bila konsentrasinya tinggi. Gejala yang paling umum keracunan timbal adalah terhambatnya pertumbuhan akar dan tajuk tanaman. Gejala 
tersebut terjadi karena timbal mengikat kuat sejumlah biomolekul seperti asam pektat dinding sel, asam-asam amino, enzim, AND dan ARN, yang diantaranya menyebabkan: gangguan terhadap pemanjangan sel dan elastisitas dinding sel, gangguan keselarasan mikrotubulus selama pembelahan sel, mempercepat penuaan jaringan dengan meningkatnya aktivitas phosphatase, amylase dan peroxidase, penurunan kandungan protein dan karbohidrat yang dibutuhkan untuk pertumbuhan normal, mengurangi laju fotosintesis dan transpirasi dikarenakan penghambatan rantai transpor elektron di dalam mitokondria dan kloroplas. Timbal juga dikenal dapat mengurangi serapan dan akumulasi ion yang penting untuk kesehatan tanaman seperti kalsium, fosfor dan nitrogen (khususnya dalam fiksasi nitrogen dalam nodul akar kacang-kacangan).

Tingkat respon keempat genus tanaman hias terhadap paparan berbagai konsentrasi logam timbal $(\mathrm{Pb})$ sebagaimana tersaji pada Gambar 5 menunjukkan bahwa genus Codiaeum (G1) memiliki rata-rata pertumbuhan luas daun pertanaman paling besar, baik pada perlakuan berbagai konsentrasi logam timbal $(\mathrm{Pb})$, diikuti oleh genus Heliconia (G2), Eichornia (G4) dan Marantha (G3). Hal tersebut menunjukkan tanaman genus Codiaeum (G1) memiliki kemampuan beradaptasi dan lebih toleran terhadap paparan berbagai konsentrasi logam timbal $(\mathrm{Pb})$ dibanding ketiga genus lainnya, walau terjadi penghambatan pertumbuhannya tetapi masih mampu menghasilkan penambahan luas daun yang lebih besar dibanding ketiga genus lainnya.

Spesies tanaman yang toleran dan adaptif terhadap lingkungan yang mengandung logam memiliki mekanisme pertahanan yang melindungi beberapa aktivitas fisiologis vital untuk mengurangi kerusakan yang diakibatkan oleh bentukbentuk oksigen reaktif karena stress yang diakibatkan oleh adanya kandungan logam. Tingkat stres tanaman akan semakin meningkat seiring dengan peningkatan kadar logam berat di dalam lingkungan tumbuhnya. Peningkatakan kadar logam berat dalam media tanam dapat mengakibatkan terjadinya perubahan fisiologi yang mengakibatkan terjadinya gangguan pertumbuhan, apabila senyawa logam berat terlarut terambil oleh tanaman.

Respon tanaman sebagai pengaruh perlakuan berbagai taraf konsentrasi logam timbal $(\mathrm{Pb})$ terhadap pertumbuhan luas daun per tanaman empat genus tanaman hias (Codiaeum (G1), Heliconia (G2), Marantha (G3) dan Eichornia (G4)) yang diamati selama umur 5 minggu setelah tanam, sebagaimana tersaji dalam Gambar 6, menunjukkan bahwa pertumbuhan luas daun keempat genus tanaman hias tersebut sangat terpengaruh pada semua taraf konsentrasi logam timbal. Penurunan pertumbuhan ratarata luas daun per tanaman keempat genus tanaman hias sudah terlihat nyata pada taraf konsentrasi 400 ppm $\mathrm{Pb}$ (logam timbal) sejak minggu pertama pengamatan sampai umur 5 minggu setelah tanam dibanding kontrol 
(tanpa pencemar timbal). Hal ini selaras dengan hasil penelitian Borker et.al. (2013) yang menunjukkan bahwa pertumbuhan Eichornia sangat terpengaruh pada semua taraf konsentrasi logam berat jenis kadmium (Cd) pada media tumbunya dimana luas daun pada umur 12 hari rata-rata pada kadar 75 ppm sebesar $7.05 \mathrm{~cm}$ lebih kecil dibanding kontrol sebesar $12.28 \mathrm{~cm} 2$.

\section{KESIMPULAN}

Kemampuan toleransi dan adaptasi tanaman genus Codiaeum terhadap paparan berbagai taraf konsentrasi logam timbal $(\mathrm{Pb})$ cenderung lebih tinggi dibanding genus Heliconia, Eichornia dan Marantha.

Penurunan pertumbuhan rata-rata tinggi tanaman dan jumlah daun per tanaman dari empat genus tanaman hias (Codiaeum, Heliconia, Marantha dan Eichornia) terjadi secara nyata pada taraf konsentrasi $\mathrm{mg} \mathrm{Pb}$. $\mathrm{Kg}^{-1}$ serta $400 \mathrm{mg} \mathrm{Pb} . \mathrm{Kg}^{-1}$ pada parameter rata-rata luas daun per tanaman dibanding kontrol selama umur 5 minggu setelah tanam.

\section{UCAPAN TERIMA KASIH}

Ucapan terima kasih disampaikan kepada Direktorat Jenderal Pendidikan Tinggi Kementrian Riset, Teknologi dan Pendidikan Tinggi melalui Direktorat Penelitian dan Pengabdian kepada Masyarakat dan DIPA Kopertis Wilayah VII Jawa Timur yang telah memberikan dana penelitian dalam program Penelitian Hibah Bersaing.

\section{REFERENSI}

Anonimous. 2012. Informasi teknis budidaya tanaman pot dan lanskap. Seri tanaman hias potensial penyerap polutan. Direktorat Jenderal Hortikultura. Direktorat Budidaya dan Pascapanen Florikultura. Jakarta. 94 pp.

Borker AR, Mane AV, Saratalle GD, Pathade GR. 2013. Phytoremediation potential of Eichhornia crassipes for the treatment of cadmium in relation with biochemical and water parameters. Emir. J. Food Agric., 25 (6): 443-456.

Ernst W.H.O. 2006. Evolution of metal tolerance in higher plants. For. Snow Landsc. Res., 80 (3): 251-274.

Feller A.K. 2000. Phtoremediation of soils and water contaminated with arsenicals from former chemical warfare installation. Di dalam: Wise DL, Trantolo DJ., Cichon EJ., Inyang HI., Stottmeister U (ed). Bioremediation of Contaminated Soils. Mark Dekker inc. New York. pp. 771-786.

Gusnita D., 2012. Pencemaran logam berat timbale $((\mathrm{Pb})$ di Udara dan upaya penghapusan bensin bertimbal. Berita Dirgantara 15(3):95-101.

Hidayati, N. 2005. Fitoremediasi dan potensi tumbuhan hiperakumulator (ulasan). J. Hayati. 12: 35-40.

John R, Ahmad P, Gadgil K, Sharma S. 2008. Effeect of cadmium and lead on growth, biochemical parameters and uptake in lemna polyrrhiza L. Plant Soil Environ., 54(6):262-270.

Lamhamdi M., O. El Galiau, A. Bakrim, J.C.N. Muniz, M.A. Estevez, A. Aarab, R. Lafont. 2013. Effect of lead stress on mineral content and growth of wheat (Triticum aesticum) and spinach (Spinacia oleracea) seedlings. Saudi Journal of Bio Sci. 20: 29-36. 
Mahmoud, W.H. and El-Betagy, 1998. Isolation,identification and potential use of lead reduction from heavy metal polluted soil. Menufiya J.Agric.Res. 23: $1461-1473$.

Sharma, P., Dubey, R.S., 2005. Lead toxicity in plants. Braz.J. Plant Physiol. 17: 3552.
Tlustos, P., J. Szakova, J. Hruby, I. Hartman, J. najmanova, J. Nedelnik, D. Pavlikova, M. Batysta. 2006. Removal of $\mathrm{As}, \mathrm{Cd}, \mathrm{Pb}, \mathrm{N}, \mathrm{Zn}$ from contaminated soil by high biomass producing plants. Plant Soil Environ.52(9):413-423. 